\title{
Sociodemographic Differences in Health Awareness and Oral Health in Pregnant Women
}

\section{Soziodemografische Unterschiede im Gesundheitsbewusstsein und der Mundgesundheit bei Schwangeren}

\section{(우(1) (오 $\ominus$}

\author{
Authors \\ Anna-Maria Kühle ${ }^{1}$, Jürgen Wacker ${ }^{1,2}$ \\ Affiliations \\ 1 Frauenklinik, Fürst-Stirum-Klinik, Bruchsal, Germany \\ 2 Frauenklinik, akademisches Lehrkrankenhaus der \\ Universität Heidelberg, Heidelberg, Germany
}

Key words

bacterial infection, gestational diabetes, premature birth, screening

Schlüsselwörter

bakterielle Infektion, Gestationsdiabetes, Frühgeburt, Vorsorge

received

18. 12.2019

accepted after revision

22.6. 2020

Bibliography

DOI https://doi.org/10.1055/a-1205-0601

Geburtsh Frauenheilk 2020; 80: 834-843 ㄷ Georg Thieme

Verlag KG Stuttgart · New York | ISSN 0016-5751

\section{Correspondence}

Anna-Maria Kühle

Frauenklinik, Fürst-Stirum-Klinik

Gutleutstraße 1-14, 76646 Bruchsal, Germany

annikuehle@gmail.com

$\circledast$

Deutsche Version unter:

https://doi.org/10.1055/a-1205-0601

\section{ABSTRACT}

Objective The aim of this study was to determine the present oral health status of pregnant women depending on selected sociodemographic differences and deduce any resulting consequences for health prevention.

Methods The participants' data of relevance to the study such as age, school leaving qualification, migration background, smoking habits or last dentist visit were recorded using a questionnaire. The subsequent dental check-up concen- trated on open carious lesions, any initiated root canal treatments and missing teeth. Finally, the Periodontal Screening Index was recorded to diagnose the presence of any gingivitis or periodontitis. The subsequent biometric evaluation comprised descriptive data analysis, $\mathrm{x}^{2}$ test and logistical regression.

Results The higher the school leaving qualification, the lower the probability that a pregnant woman smoked prior to pregnancy (OR $0.291 ; 95 \% \mathrm{Cl} 0.114-0.743$ ) and that tartar was diagnosed (OR 0.424; 95\% Cl 0.185-0.973). Regular dentist visits (OR 4.026; 95\% Cl 1.613-10.049) increase with the attained school leaving qualification. There is a greater chance that women born in Germany taking part in the study were aware of dental risks in pregnancy (OR 2.652; 95\% Cl 1.2855.472 ) and attended the dentist during pregnancy (OR 2.507; $95 \% \mathrm{Cl} 1.281-4.907)$.

Conclusion The rate of awareness of the risks and consequences of pregnancy for oral health must be increased. The main aim for primary prophylaxis should be a reduction in the periodontal bacteria and caries of the mother and father.

\section{ZUSAMMENFASSUNG}

Fragestellung Ziel dieser Studie ist es, einen aktuellen Status der Mundgesundheit von Schwangeren in Abhängigkeit ausgewählter soziodemografischer Unterschiede zu ermitteln und gegebenenfalls daraus Konsequenzen für die Gesundheitsprävention abzuleiten.

Methoden Anhand eines Fragebogens wurden zunächst die studienrelevanten Daten der Teilnehmerinnen wie das Alter, der Schulabschluss, der Migrationshintergrund, das Rauchverhalten oder der letzte Zahnarztbesuch erfasst. Eine anschließende zahnärztliche Kontrolluntersuchung konzentrierte sich auf offene kariöse Läsionen, begonnene Wurzelkanalbehandlungen und fehlende Zähne. Um eine eventuell vorliegende Gingivitis oder Parodontitis zu diagnostizieren, ermittelte man abschließend den Parodontalen Screening Index. Deskriptive Datenanalyse, $X^{2}$-Test und logistische Regression in der anschließenden biometrischen Auswertung. 
Ergebnisse Je höher der Schulabschluss, desto geringer ist die Wahrscheinlichkeit, dass eine Schwangere vor der Schwangerschaft geraucht hat (OR 0,291; 95\%-KI 0,1140,743 ) und Zahnstein diagnostizierbar ist (OR 0,424; 95\%-KI 0,185-0,973). Regelmäßige Zahnarztbesuche (OR 4,026; 95\%-KI 1,613-10,049) nehmen mit der Höhe des Schulabschlusses zu. Bei den in Deutschland geborenen Frauen ist die Chance größer, dass eine Studienteilnehmerin eine Aufklärung über zahnärztliche Risiken in der Schwangerschaft erhal- ten hat (OR 2,652; 95\%-KI 1,285-5,472) und während der Schwangerschaft beim Zahnarzt war (OR 2,507; 95\%-KI 1,281-4,907).

Schlussfolgerung Die Aufklärungsrate über Risiken und Folgen einer Schwangerschaft für die Mundgesundheit muss erhöht werden. Hauptziel im Sinne einer Primärprophylaxe sollte die parodontale Keim- und Kariesreduktion von Mutter und Vater sein.

\section{Introduction and Objective}

"Every child costs its mother a tooth". This folk wisdom remains a firm tenet to this day [1,2] but leads in professional circles to contentious discussions.

Pregnancy requires constant coordination between the mother's body and the developing baby, resulting in hormonal, respiratory, cardiovascular and metabolic fluctuations [3,4].

As early as 1933, initial studies described an increased incidence of gingivitis during pregnancy [5,6]. Other studies followed, which confirmed a significant rise in gingivitis in pregnant women [7-10]. Besides plaque, pocket depth also increases temporarily during pregnancy and diminishes again after the pregnancy [11]. Gingivitis and periodontitis occur as a result. The poorer oral health in pregnant women compared with non-pregnant women was shown in other studies [12-14].

The probability of developing gingivitis is significantly higher in the third trimester than at the start of the pregnancy $(p \leq 0.001)$ [12]. Improved oral hygiene and appropriate periodontal therapy before or during the pregnancy can prevent gingivitis and periodontitis [12] and significantly reduce the stress level of pregnant women [10].

To date, what leads to the increased incidence of gingivitis in pregnancy has not been conclusively explained. A hormonal background is suspected [15]. Studies report specific progesterone and oestrogen receptors in periodontal tissue $[15,16]$ and in the periodontium $[17,18]$. It has been confirmed that Porphyromonas gingivalis, Filifactor alocis, Treponema denticola and combinations of these lead to inflammatory reactions in pregnancy [19].

The risk of preterm birth with an underweight baby increases as soon as periodontal disease is present in the mother [20-22]. An elevation of C-reactive protein has been found in both gestational gingivitis and gestational diabetes mellitus $[9,19]$. The Creactive protein was increased by $325 \%$ in acute gestational gingivitis [19]. Thus, both gestational diabetes mellitus and gingivitis could be the cause of preterm birth with a low birth weight infant $[9,19]$. Besides the approximately $13 \%$ of pregnant women who suffer from gestational diabetes [23], 60-80\% of existing gestational diabetes is not recognised [24]. Gestational periodontitis has been linked with preterm births as well as with an increased risk of pre-eclampsia and very low birth weight [25-27].

Other problems are the falling salivary $\mathrm{pH}$ level, the reduction in buffering capacity and falling calcium and phosphate content of the saliva with advancing pregnancy [28].
As the foetus grows, the mother's stomach capacity diminishes. Pregnant women therefore consume smaller portions more often, which in turn promotes the development of caries [14]. Possible vomiting, especially in the first trimester, likewise represents an increased erosion and caries risk $[14,29]$. Consumption of hypercaloric food in pregnancy harms the mother herself, on the one hand, and on the other hand the child receives a "lifetime burden" [23].

Minimising and controlling these problems can be achieved by good oral hygiene in pregnant women and furthermore by specific nutritional counselling [15, 23].

A significant relationship between the child's future oral health and maternal oral health has been shown $[30,31]$. The pregnant woman's oral health thus influences not only her own health but also that of her child [9].

More than $60 \%$ of the surveyed pregnant women perceived their knowledge regarding the importance of oral hygiene as insufficient, both in connection with their own teeth and with those of their baby [32]. Only $24 \%$ received specific pregnancy-related oral hygiene instruction from their dentist [33]. In a study by the German Midwives' Association, 53.6\% of midwives recommended visiting a dentist during pregnancy [34]. Targeted identification and minimisation of risks and detailed nutritional counselling were shown to lead to an improvement in the oral health of both the pregnant women and their children [35-37]. Early dental health promotion can deliver a further important contribution to the oral health of mother and child [38]. Independent of which concept of early dental health promotion is considered, close interdisciplinary cooperation appears essential [33, 36, 38, 39]. Currently there is not yet a firmly established interdisciplinary prophylaxis concept throughout Germany for pregnant women or women planning pregnancy. It would be desirable if the proverb "a tooth for every child", whether true or not, were to sensitise society to the problematic changes in oral health that can be associated with pregnancy. With the main hypothesis that "Individual initiative and health behaviour of study participants depends on sociodemographic factors and have effects on their oral health" a study of the oral health of pregnant women and women who have recently given birth was conducted in 2018 as part of a dissertation.

Soundly based knowledge of the study participants' awareness, oral health and selected sociodemographic data should make it possible to ascertain the need for targeted preventive measures. In consequence, awareness-raising measures and a 
preventive programme in the study region should be contemplated and stimulated.

\section{Methods}

\section{Preparatory measures}

To obtain statistically valid information and the same time meet ethical guidelines, a case number of $n=200$ was regarded as reasonable. An informed consent form and the questionnaire containing 15 questions were designed. Participants were asked, for example, about school leaving qualification and country of birth, smoking before and during pregnancy and the occurrence of bleeding gingiva. The Heidelberg ethics committee approved the study (file reference: S-157/2018).

\section{Participation criteria}

The study participants had to be between 18 and 35 years old, be at least 27 weeks pregnant and birth in the Fürst Stirum Clinic Bruchsal had to be no more than 5 days previously. The patients or a family member had to have a command of German or English. Exclusion criteria were poor compliance and systemic and infectious diseases.

\section{Clinical procedure}

The clinical studies were conducted in 200 patients of Fürst Stirum Clinic Bruchsal from May 2018 to September 2018. Women giving birth at this time lived either through the cariogenic Christmas period with its citrus fruits or the summertime, characterised by heat, which can support bacterial growth.

All patients registered as inpatients on a day chosen at random and who met the inclusion criteria were allowed to take part. The study participants were first informed about the planned study and were informed about data protection guidelines. At least $24 \mathrm{~h}$ later the 15 questions of the questionnaire were discussed with each study participant and they then had a dental examination with mirror, dental loupes and corresponding loupe lamp in the patient's room. Obvious carious defects, initiated root canal treatments and visible extraction wounds/sockets were noted. In the second stage of the clinical examination the periodontal screening index was recorded, using a periodontal probe, two mirrors and loupe with lamp [40]. All equipment was sterilised before use. The examination was performed in compliance with the Professional Code for Dentists of the Dental Association of BadenWürttemberg und the Declaration of Helsinki in their current versions. Answering the questionnaire and the dental examination lasted about 10-15 minutes in total per study participant. The study was not associated with any risks for the patients. The clinical part concluded with a discussion of the findings and information about correct oral hygiene in the baby and small child.

- Fig. 1 gives a flowchart overview of the clinical procedure.

\section{Statistical analysis}

All data were transferred directly from the questionnaire into the statistics program IBM SPSS Statistics Version 19 (IBM Corp. Released 2010. IBM SPSS Statistics for Windows, Version 19.0. Armonk, NY: IBM Corp., USA). Because of the exploratory character

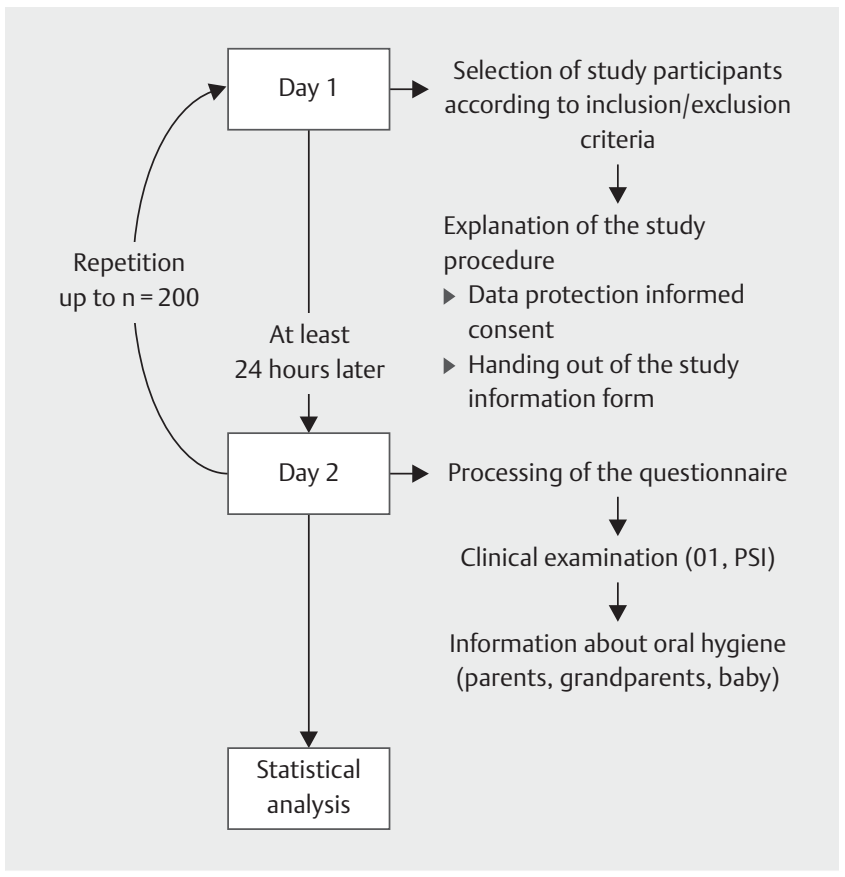

- Fig. 1 Flowchart of the clinical study.

of the study, the $p$ values do not have any confirmatory value. The descriptive analysis of the obtained data with relative and absolute frequencies was followed by an examination of the associations between independent variables and 8 target variables (school leaving qualification, country of birth, open carious lesions, PSI, dentist visit before/during pregnancy, awareness in pregnancy, smoking before/during pregnancy) using $x^{2}$ test. The influence of significant results $(p \leq 0.05)$ on the dependent variable was then analysed using univariate logistical regression. Significant results in this analysis ( $p \leq 0.05)$ were in turn included in a multivariate logistical analysis. - Fig. 2 illustrates the statistical analysis sequence.

\section{Results}

All study participants $(n=200)$ answered the questionnaire in full. Nobody withdrew from the study.

\section{Descriptive data analysis}

Seven (3.5\%) study participants had a tooth extracted in this or in previous pregnancies. Nearly half $(96,48 \%)$ of those surveyed suffered subjectively from gingival bleeding. 92 (46\%) study participants reported negative changes during pregnancy. Open carious lesions were diagnosed in 54 (27\%) of participating women. 74 (37\%) study participants had a PSI score of 3 or 4 . These study participants therefore were suffering from gingivitis or periodontitis that required treatment. 128 (64\%) study participants visited their dentist for prevention, routine check-up or other treatment during pregnancy. Of the 200 women taking part, 39, that is, nearly $20 \%$, did not go to the dentist regularly before their preg- 


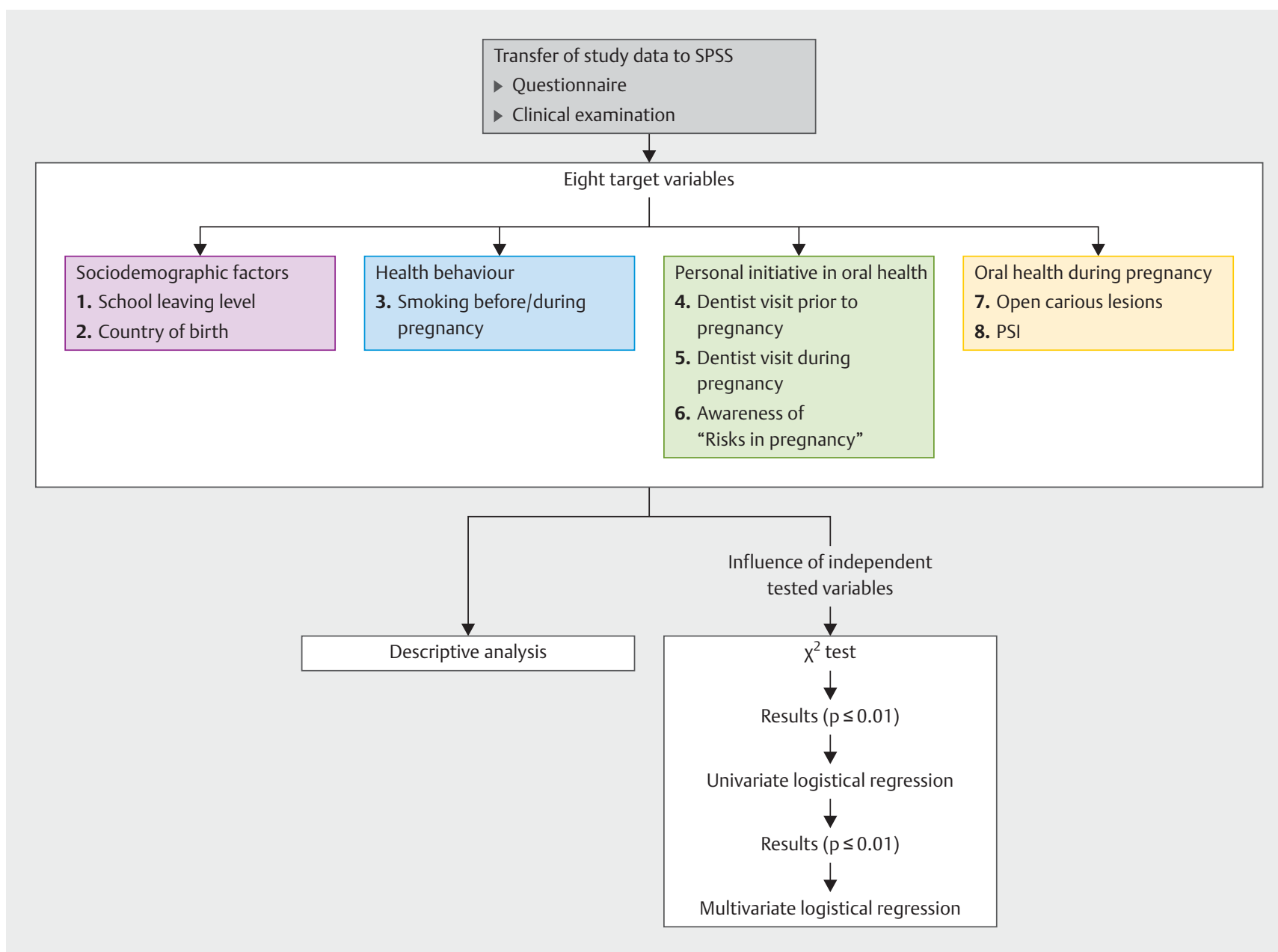

- Fig. 2 Flowchart of the statistical analysis.

nancy. At 111 (55.5\%) study participants, more than half of the women taking part were not aware of dental risks in pregnancy.

$160(80 \%)$ study participants had completed intermediate or upper secondary school or had equivalent school leaving qualifications. Six (3\%) study participants had no school leaving qualification. The patients' origin was described only by the question about their country of birth and how long they have lived in Germany was not a questionnaire item. 144 (72\%) participants were born in Germany. 47 (23.5\%) study participants smoked before and/or in pregnancy. - Table 1 lists all nationalities of the study participants. - Table 2 shows an overview of the results of the descriptive analysis.

\section{Multivariate data analysis}

If a dentist visit prior to pregnancy is considered as a target parameter using the multiple regression model, it can be predicted that when there are fewer carious lesions (OR 0.239; $95 \% \mathrm{Cl}$ 0.096-0.597), high school leaving qualification (OR 3.877; 95\% $\mathrm{Cl}$ 1.516-9.917) and existing awareness (OR 3.256; $95 \% \mathrm{Cl}$ 0.017 ) the chance of a dentist visit prior to pregnancy is greater. Participants born in Germany went to the dentist significantly more often during pregnancy (OR 2.507; 95\% Cl 1.281-4.907) and were more aware of dental risks (OR 2.652; 95\% Cl 1.2855.472).

The chance of diagnosing caries is higher if the study participant did not go to the dentist before her pregnancy (OR 0.244; $95 \% \mathrm{Cl} 0.102-0.582$ ) and/or had a PSI of 3 or 4 (OR 3.400; $95 \%$ Cl 1.578-7.324).

The higher the periodontal screening index, the more probably the study participants suffered subjectively from gingival bleeding (OR 4.652; 95\% Cl 2.227-9.718), had open carious sites (OR 3.768; $95 \% \mathrm{Cl} 1.655-8.580$ ) or visible tartar (OR 3.918; $95 \% \mathrm{Cl}$ 1.877-8.179).

With a lower school leaving qualification, the probability is higher that the study participant will have tartar diagnosed (OR $0.424 ; 95 \% \mathrm{Cl} 0.185-0.973)$, that she did not go to the dentist before pregnancy (OR 4.026; $95 \% \mathrm{Cl} 1.613-10.049)$ and that she smoked before pregnancy (OR 0.291; 95\% Cl 0.114-0.743).

Study participants who smoke or smoked before pregnancy are more likely to have a lower school leaving qualification (OR $0.220 ; 95 \% \mathrm{Cl} 0.103-0.471$ ) and a poorer subjective feeling of oral health (OR 1.639; $95 \% \mathrm{Cl} 1.069-2.513)$. 
- Table 1 Detailed overview of countries of birth.

\begin{tabular}{|l|c|}
\hline Country of birth & Number of cases (\%) \\
\hline Germany & $144(72.0)$ \\
\hline Russia & $12(6.0)$ \\
\hline Turkey & $2(1.0)$ \\
\hline Kazakhstan & $5(2.5)$ \\
\hline Former Yugoslavia & $2(1.0)$ \\
\hline Iraq & $1(0.5)$ \\
\hline Eritrea & $1(0.5)$ \\
\hline China & $1(0.5)$ \\
\hline Kosovo & $4(2.0)$ \\
\hline Poland & $2(1.0)$ \\
\hline Ireland & $2(1.0)$ \\
\hline Syria & $2(1.0)$ \\
\hline Hungary & $2(1.0)$ \\
\hline Romania & $4(2.0)$ \\
\hline India & $1(0.5)$ \\
\hline Netherlands & $1(0.5)$ \\
\hline Tunisia & $1(0.5)$ \\
\hline Sri Lanka & $1(0.5)$ \\
\hline Macedonia & $1(0.5)$ \\
\hline Ukraine & $2(1.0)$ \\
\hline Algeria & $1(0.5)$ \\
\hline Colombia & $1(0.5)$ \\
\hline Italy & $1(0.5)$ \\
\hline Croatia & $1(0.5)$ \\
\hline Cameroon & $1(0.5)$ \\
\hline Serbia & $2(1.0)$ \\
\hline Albania & $1(0.5)$ \\
\hline Moldova & $1(0.5)$ \\
\hline Total & \\
\hline
\end{tabular}

Awareness of dental risks in pregnancy was more common in women born in Germany (OR 2.61; 95\% Cl 1.270-5.350) and if a dentist was visited before pregnancy (OR 3.1; 95\% Cl 1.3057.364).

\section{Summary of the most relevant correlations}

The individual health prevention and the subjective and objective oral health correlate with the school leaving qualification and country of birth.

Based on the correlations, the following associations are conceivable:

1. Neglect of individual health prevention (e.g., smoking before/ during pregnancy, individual dental care/oral hygiene) is a consequence of less school education.

2. School education and country of birth have a strong influence on the frequency of dentist visits before and during pregnancy.
- Table 2 Table showing a summary of the descriptive analysis of all parameters with case number $\mathrm{n}=200$.

\begin{tabular}{|l|c|}
\hline Parameter & Number of cases (\%) \\
\hline Tooth extraction in pregnancy & $7(3.5)$ \\
\hline $\begin{array}{l}\text { Subjective suffering from gingival } \\
\text { bleeding }\end{array}$ & $96(48)$ \\
\hline Visible open carious lesions & $54(27)$ \\
\hline Diagnosed PSI of 3 or 4 & $74(37)$ \\
\hline $\begin{array}{l}\text { Intermediate and higher secondary } \\
\text { school leaving qualification }\end{array}$ & $160(80)$ \\
\hline Country of birth: Germany & $144(72)$ \\
\hline Smoking before/during pregnancy & $47(23.5)$ \\
\hline Dentist visits in pregnancy & $128(64)$ \\
\hline Regular dentist visits before pregnancy & $39(19.5)$ \\
\hline Awareness of dental risks in pregnancy & $89(44.5)$ \\
\hline
\end{tabular}

3. Pregnant women go to the dentist more often during pregnancy because they are more aware of dental risks in pregnancy.

4. Pregnant women are more aware of dental risks in pregnancy if they go to the dentist regularly.

- Table 3 gives an overview of the most important correlations.

\section{Discussion}

Due to the high fluctuation in the patients' rooms, an external treatment room on the ward might possibly have brought greater calm to the study situation. The problem of data protection in double rooms would also have been easier to solve. The decision to conduct the study in the patient's room was not made because of lack of space, however. One should be aware, including when planning further studies, that the study participants are women, some of whom are shortly before or after delivery for whom it was not possible to get up. A few had to observe absolute bed rest because of premature labour or problems in pregnancy. The majority of the study participants had a new-born baby with them, which had to be regularly nursed/fed/weighed/changed or had its temperature measured.

With the intention of documenting gingival and periodontal status as well as the influencing variables at the end of pregnancy, it had been decided to start participation only from the third trimester onwards. The results are thereby more comparable as all study participants had been exposed for at least six months to the hormonal fluctuations of pregnancy. Furthermore, how the measured values change after pregnancy would also be of interest. Ibrahim et al. selected this route in their study [41]. A further fact to clarify would be the PSI prior to pregnancy. All parameters diagnosed in this study are actual values and had no follow-up. Therefore, no confirmed information about an improvement or deterioration of periodontal status can be inferred. 
- Table 3 Table showing the multivariate data analysis of target and independent variables.

\begin{tabular}{|c|c|c|c|c|}
\hline \multirow[t]{2}{*}{ Target variable } & \multirow[t]{2}{*}{ Independent variables } & \multirow[t]{2}{*}{$\operatorname{Exp}(B)(O R)$} & \multicolumn{2}{|c|}{ 95\% confidence interval for Exp (B) } \\
\hline & & & Lower value & Upper value \\
\hline \multirow[t]{2}{*}{ Open carious lesions } & Dentist visit before pregnancy & 0.244 & 0.102 & 0.582 \\
\hline & Periodontal screening index & 3.400 & 1.578 & 7.324 \\
\hline \multirow[t]{3}{*}{ Periodontal screening index } & Suffering from gingival bleeding & 4.652 & 2.227 & 9.718 \\
\hline & Open carious lesions & 3.768 & 1.655 & 8.580 \\
\hline & Tartar & 3.918 & 1.877 & 8.179 \\
\hline \multirow[t]{3}{*}{ Dentist visit before pregnancy } & Occlusal lesions & 0.239 & 0.096 & 0.597 \\
\hline & School leaving qualification & 3.877 & 1.516 & 9.917 \\
\hline & Awareness in pregnancy & 3.256 & 1.230 & 8.622 \\
\hline \multirow[t]{2}{*}{ Awareness in pregnancy } & Dentist visit before pregnancy & 3.100 & 1.305 & 7.364 \\
\hline & Origin & 2.607 & 1.270 & 5.350 \\
\hline \multirow[t]{2}{*}{ Smoking behaviour } & School leaving qualification & 0.220 & 0.103 & 0.471 \\
\hline & Subjective feeling of oral health & 1.639 & 1.069 & 2.513 \\
\hline \multirow[t]{3}{*}{ School leaving qualification } & Tartar & 0.424 & 0.185 & 0.973 \\
\hline & Dentist visit before pregnancy & 4.026 & 1.613 & 10.049 \\
\hline & Smoking before pregnancy & 0.291 & 0.114 & 0.743 \\
\hline \multirow[t]{2}{*}{ Country of birth Germany } & Dentist visit during pregnancy & 2.507 & 1.281 & 4.907 \\
\hline & Awareness in pregnancy & 2.652 & 1.285 & 5.472 \\
\hline
\end{tabular}

Studies with a similar design have recorded the plaque index, among other things [11,42-48]. This provides information about the study participant's current oral hygiene. The following considerations led to the decision not to record the plaque index in this study design:

1. As mentioned above, the study was conducted in the patient's room. The plaque disclosing agents needed to stain plaque can stain objects and clothing.

2. Most of the study participants were confined to bed and often had a baby in the immediate vicinity. To disclose plaque, the study participants would have had to get up and rinse. This would have been an unacceptable situation.

3. Patients who have just come from the delivery room or who are about to give birth very probably do not take as much trouble with their oral hygiene as they would under normal circumstances. The reliability of the plaque index would therefore be doubtful.

The level of knowledge of oral health in pregnancy increases with the number of children but also with the number of years of school attendance [49]. Besides the necessary validation of the target variable "school leaving qualification", extension to "occupational status" (unemployed, part-time, full-time, parental leave) and "vocational training" (training, third-level studies) would be interesting in this connection.

Markedly reduced oral health was found in refugees, possibly because of poorer conditions with regard to non-existent preventive concepts [50]. The target variable "origin" provides no information about language knowledge and duration of residence.
A further addition would be inclusion of the place of residence (urban/rural), as done by Machuca et al. in their study [46].

Caries prevalence is increased in lower social classes [51-53]. Even if pregnant women with caries do not have a higher risk of preterm birth [54], this target variable is essential for any resulting preventive programme and is an indicator for the quality of the oral hygiene of the study participants. Tartar, present in the majority, and soft plaque increased the risk of overlooking carious defects.

Because of the rapid diagnosis and good study comparability, we decided to record the periodontal screening index. It would be interesting to learn how the measured PSI scores change after pregnancy. This was chosen by Ibrahim et al. in their study [41]. Another question to be explored is: "What was the PSI before pregnancy?" Since the diagnosed scores are actual values and do not show any progression, no secure information about an improvement or deterioration can be inferred from them.

The target variable "Awareness in pregnancy" comprises merely knowledge about risks in pregnancy. The precise and correct level of knowledge of the study participants was not tested, as Zhong et al. did in their study [55]. A detailed enquiry would possibly have given an impetus to study participants who had acquired their knowledge by private study or whose awareness was poor and could reveal gaps in knowledge. It is highly probable that fewer "yes" answers regarding awareness would have been seen in the evaluation.

Apart from an increased periodontitis risk [56], smoking in pregnancy leads to damage to the unborn child, spontaneous abortion and pregnancy complications such as ectopic pregnancy, placenta previa, placental laceration or premature rupture 


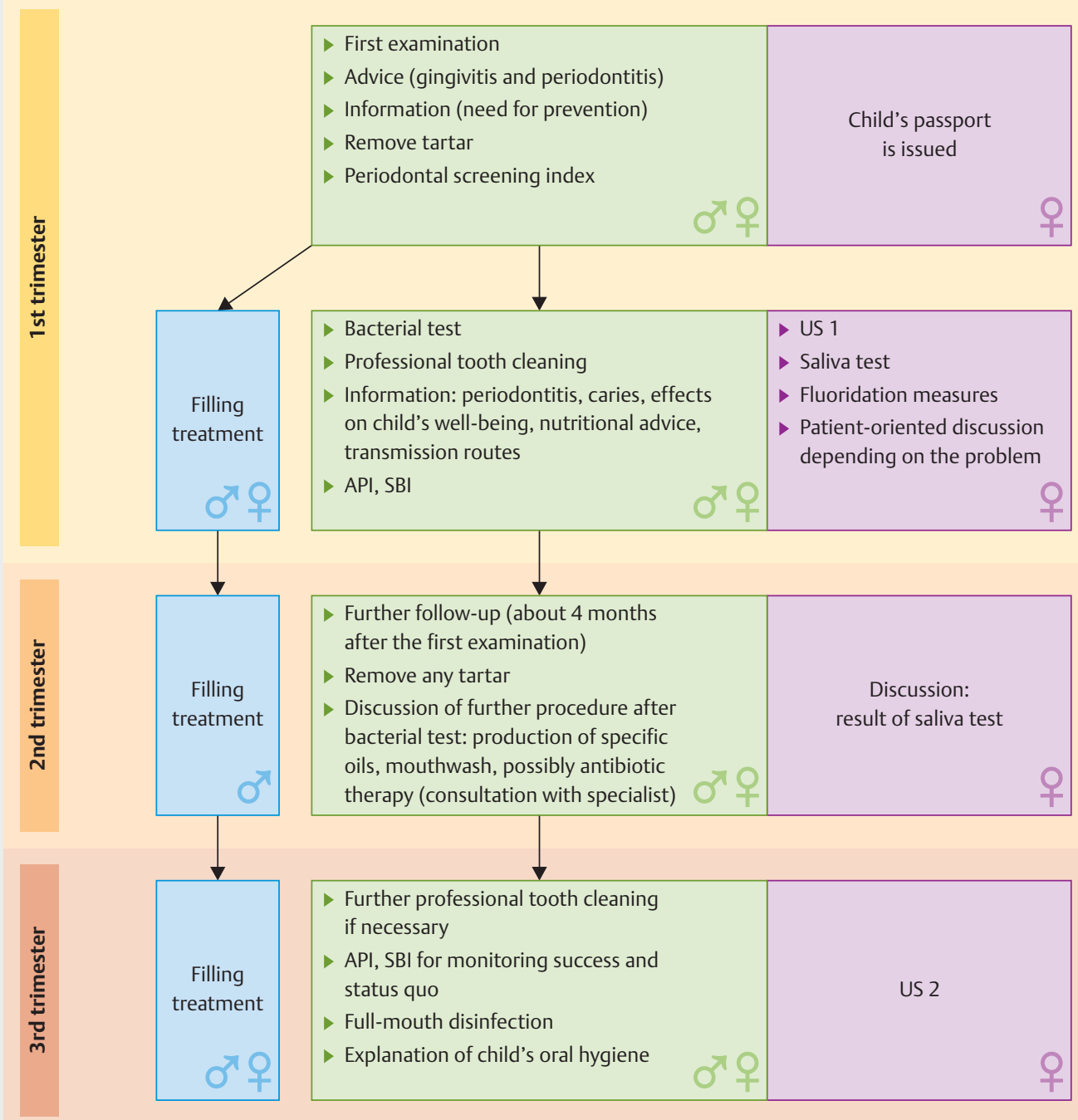

- Fig. 3 Preventive concept for parents-to-be. US = Examination pregnant women

of the membranes [57]. For these reasons alone, it was essential to evaluate the target variable "smoking" and if necessary include it in a new prevention concept as a point for awareness. It must be doubted, however, that the question on "smoking in pregnancy" was always answered truthfully if the study participants have to answer a medical professional who regards their behaviour critically. It would also be interesting to know how many pregnant women are exposed to passive smoking.

As long ago as 1999 a study showed that the plaque and bleeding index and pocket depth are greater in study participants with a low level of school education [46]. Nearly twenty years later, in 2018, the present study supports this result.

In a cross-sectional study in obstetric practices using a questionnaire, Stelmakh et al. found a rate of awareness of dental risks due to pregnancy of 53.9\% [58]. Among these women $11 \%$ visited a dentist during pregnancy after they had observed changes in their oral health [58]. The present study shows an awareness rate of $44.5 \%$. A study conducted in a similar period reports a much reduced percentage awareness rate of $24 \%$ [33]. Independent of the rise in the rate of awareness compared with 2007 (14\%) [59], prevention and antenatal care must be improved in the form of primary prevention, and also because of the high rate of diagnosis of gingivitis/periodontitis. - Fig. 3 shows a prevention concept for mothers- and fathers-to-be that we developed. In 2016272327 fathers claimed parents' allowance $[51,52,60]$. The number rose to 404676 in 2017 [60]. It therefore appears useful and essential from the microbiological aspect to include close contacts (the other parent) of the unborn child in the prevention/awareness programme. Following existing concepts for pregnant women, we developed our own prevention concept for parents-to-be for the first time [36-38, 59,61-65].

It can be found from one study [45] that only age, tooth loss and effects of pregnancy had an influence on quality of life, but not periodontal status. With an OR 4.652 and $95 \% \mathrm{Cl}$ of $2.227-$ 
9.718 this study showed that women with gingivitis or periodontitis very probably suffer from gingival bleeding also. There is a very high probability that women with untreated caries assess their oral health as poor (OR 0.338, 95\% Cl 0.177-0.647). These study results overlap with those of Martínez-Beneyto et al. [66]. Pregnant women who perceive their oral health subjectively as good exhibit fewer carious sites and a lower PSI [66].

In many studies, an association is reported between periodontitis during pregnancy, underweight new-borns, very low birth weight, pre-eclampsia and gestational diabetes [9, 25, 26,67]. These associations and complications point to the importance of this study. Based on study research $[44,46]$ the study was limited to study participants up to the age of 34 years. An extension of the study design can allow for an upwardly open age. A possibly resulting higher number of multiple pregnancies in the study participant pool could even better investigate the proverb "Every child costs the mother a tooth". According to available studies, among pregnant women with gestational diabetes $77.4 \%$ also suffer from periodontitis $[9,67]$. It would therefore be of great interest to include patients with the systemic disease diabetes mellitus specifically in further studies.

\section{Conclusions}

These results and correlations confirm the main hypothesis that "Individual initiative and health behaviour of study participants depends on sociodemographic factors and have effects on their oral health".

In the present study, fewer than half $(44.5 \%)$ of the participants were aware of the risks for their oral health. The gingivitis/ periodontitis rate was $37 \% .27 \%$ of study participants had teeth destroyed by caries. These figures and the results of this study overall suggest that a preventive programme should be developed. It must be adapted to the local situation and be feasible realistically and financially in cooperation with gynaecologists, midwives and dentists. The study results point to the need to pay special attention to and pick up immigrant families and parents with low school education. From the microbiological point of view, close contacts (other parent) of the unborn child should be included in the preventive/awareness programme. As mentioned above, our own preventive concept was developed for parents-tobe on the basis of existing concepts for pregnant women ( $\bullet$ Fig. 3 ) [36-38, 59, 61-65].

\section{Acknowledgements}

We thank the study participants and the Fürst Stirum Clinic Association for financing the required investigation instruments.

\section{Conflict of Interest}

The authors declare that they have no conflict of interest.

\section{References}

[1] Russell SL, Ickovics JR, Yaffee RA. Exploring potential pathways between parity and tooth loss among American women. Am J Public Health 2008; 98: 1263-1270. doi:10.2105/ajph.2007.124735

[2] Zadow-Dorr J. „Tag der Zahngesundheit“ beseitigt bestehende Mythen Landeszahnärztekammer Brandenburg; 16.09.2016. Online: http:// www.lzkb.de/64-Izkb/aktuelles/pressemitteilungen/654-,„tag-derzahngesundheit“-beseitigt-bestehende-mythen; last access: 20.07.2017

[3] Giglio JA, Lanni SM, Laskin DM et al. Oral health care for the pregnant patient. Dent Assist 2013; 82: 38, 40, 42 passim

[4] Patcas RG, Gnoinski W. Zehn Punkte zur zahnärztlichen Betreuung. Zahnärztliche Mitteilungen 2013; 19. Online: https://www.zm-online. de/archiv/2013/19/titel/zehn-punkte-zur-zahnaerztlichen-betreuung/; last access: 13.12 .2018

[5] Ziskin DE, Nesse G]. Pregnancy gingivitis; history, classification, etiology. Am J Orthod Oral Surg 1946; 32: 390-432

[6] Ziskin DE, Nesse GJ. Pregnancy gingivitis. Alpha Omegan 1946; 40: 20 24

[7] Ehlers V, Callaway A, Hortig W et al. Clinical parameters and aMMP-8concentrations in gingival crevicular fluid in pregnancy gingivitis. Clin Lab 2013; 59: 605-611

[8] Figuero E, Carrillo-de-Albornoz A, Martin C et al. Effect of pregnancy on gingival inflammation in systemically healthy women: a systematic review. J Clin Periodontol 2013; 40: 457-473. doi:10.1111/jcpe.12053

[9] Hartnett E, Haber J, Krainovich-Miller B et al. Oral Health in Pregnancy. J Obstet Gynecol Neonatal Nurs 2016; 45: 565-573. doi:10.1016/ j.jogn.2016.04.005

[10] Musskopf ML, Milanesi FC, Rocha JMD et al. Oral health related quality of life among pregnant women: a randomized controlled trial. Braz Oral Res 2018; 32: e002. doi:10.1590/1807-3107bor-2018.vol32.0002

[11] Gonzalez-Jaranay M, Tellez L, Roa-Lopez A et al. Periodontal status during pregnancy and postpartum. PLoS One 2017; 12: e0178234. doi:10.1371/journal.pone.0178234

[12] Kashetty M, Kumbhar S, Patil S et al. Oral hygiene status, gingival status, periodontal status, and treatment needs among pregnant and nonpregnant women: A comparative study. J Indian Soc Periodontol 2018; 22: 164-170. doi:10.4103/jisp.jisp_319_17

[13] Lasisi T], Abdus-Salam RA. Pattern of Oral Health Among a Population of Pregnant Women in Southwestern Nigeria. Arch Basic Appl Med 2018; 6: 99-103

[14] Dharmashree S, Kumar M. Oral Health Status of 300 Pregnant Women Attending Antenatal Clinics of Visahakapatnam City - One Year Descriptive Cross-Sectional Study. International Journal of Contemporary Medical Research 2018. doi:10.21276/ijcmr.2018.5.6.11. Online: https:// www.ijcmr.com/uploads/7/7/4/6/77464738/ijcmr_2058_v1.pdf; last access: 15.07 .2020

[15] Wu M, Chen SW, jiang SY. Relationship between gingival inflammation and pregnancy. Mediators Inflamm 2015; 2015: 623427. doi:10.1155/ 2015/623427

[16] Vittek J, Hernandez MR, Wenk EJ et al. Specific estrogen receptors in human gingiva. J Clin Endocrinol Metab 1982; 54: 608-612. doi:10.1210/ jcem-54-3-608

[17] Jonsson D, Andersson G, Ekblad E et al. Immunocytochemical demonstration of estrogen receptor beta in human periodontal ligament cells. Arch Oral Biol 2004; 49: 85-88

[18] Kawahara K, Shimazu A. Expression and intracellular localization of progesterone receptors in cultured human gingival fibroblasts. J Periodontal Res 2003; 38: 242-246

[19] Gogeneni H, Buduneli N, Ceyhan-Ozturk B et al. Increased infection with key periodontal pathogens during gestational diabetes mellitus. J Clin Periodontol 2015; 42: 506-512. doi:10.1111/jcpe.12418 
[20] Chambrone L, Guglielmetti MR, Pannuti CM et al. Evidence grade associating periodontitis to preterm birth and/or low birth weight: I. A systematic review of prospective cohort studies. J Clin Periodontol 2011; 38: 795-808. doi:10.1111/j.1600-051X.2011.01755.x

[21] Pihlstrom BL, Michalowicz BS, Johnson NW. Periodontal diseases. Lancet 2005; 366: 1809-1820. doi:10.1016/s0140-6736(05)67728-8

[22] Xiong X, Buekens P, Fraser WD et al. Periodontal disease and adverse pregnancy outcomes: a systematic review. BJOG 2006; 113: 135-143. doi:10.1111/j.1471-0528.2005.00827.x

[23] Baur KM, Wacker J. Eine Last fürs Leben. In: Badische Neuste Nachrichten - Bruchsaler Rundschau. 74. Jhg, Nr. 72, Karlsruhe; 26.03.2019

[24] Wacker J, Sillem M, Bastert G, Beckmann MW. Therapiehandbuch Gynäkologie und Geburtshilfe: Berlin, Heidelberg: Springer; 2019

[25] Corbella S, Taschieri S, Del Fabbro M et al. Adverse pregnancy outcomes and periodontitis: A systematic review and meta-analysis exploring potential association. Quintessence Int 2016; 47: 193-204. doi:10.3290/ j.qi.a34980

[26] Guimaraes AN, Silva-Mato A, Siqueira FM et al. Very low and low birth weight associated with maternal periodontitis. J Clin Periodontol 2012; 39: 1024-1031. doi:10.1111/jcpe.12000

[27] Ha JE, Jun JK, Ko HJ et al. Association between periodontitis and preeclampsia in never-smokers: a prospective study. J Clin Periodontol 2014; 41: 869-874. doi:10.1111/jcpe.12281

[28] Laine M, Pienihäkkinen K. Salivary buffer effect in relation to late pregnancy and postpartum. Acta Odontol Scand 2000; 58: 8-10

[29] Laine MA. Effect of pregnancy on periodontal and dental health. Acta Odontol Scand 2002; 60: 257-264

[30] Shearer DM, Thomson WM, Broadbent JM et al. Maternal oral health predicts their children's caries experience in adulthood. J Dent Res 2011; 90: 672-677. doi:10.1177/0022034510393349

[31] Weintraub JA, Prakash P, Shain SG et al. Mothers' caries increases odds of children's caries. J Dent Res 2010; 89: 954-958. doi:10.1177| 0022034510372891

[32] Gaszynska E, Klepacz-Szewczyk J, Trafalska E et al. Dental awareness and oral health of pregnant women in Poland. Int J Occup Med Environ Health 2015; 28: 603-611. doi:10.13075/ijomeh.1896.00183

[33] Odermatt T, Schötzau A, Hoesli I. Orale Gesundheit und Schwangerschaft - Patientinnenbefragung anhand eines Fragebogens. Z Geburtshilfe Neonatol 2017; 221: 180-186. doi:10.1055/s-0043-108762

[34] Wagner $Y$, Heinrich-Weltzien R. Midwives' oral health recommendations for pregnant women, infants and young children: results of a nationwide survey in Germany. BMC Oral Health 2016; 16: 36. doi:10.1186/s12903016-0192-1

[35] Gomez SS, Emilson C-G, Weber AA et al. Prolonged effect of a motherchild caries preventive program on dental caries in the permanent $1 \mathrm{st}$ molars in 9 to 10-year-old children. Acta Odontol Scand 2007; 65: 271274. doi: $10.1080 / 00016350701586647$

[36] Günay H, Meyer K. Interdisziplinäre Gesundheitsfrühförderung. Praev Gesundheitsf 2010; 5: 326-339. doi:10.1007/s11553-010-0265-y

[37] Meyer K, Geurtsen W, Günay H. An early oral health care program starting during pregnancy. Clin Oral Investig 2010; 14: 257-264

[38] Günay H, Meyer K. Was bringt die zahnärztliche Frühprävention? 2013. Online: https://www.zm-online.de/zm-starter/junge-zahnmedizin/wasbringt-die-zahnaerztliche-fruehpraevention/; last access: 28.02.2019

[39] Marla V, Chettiar R, Roy D et al. The Importance of Oral Health during Pregnancy: A review. MedicalExpress 2018. doi:10.5935/medical express.2018.mr.002

[40] Bateman RM, Sharpe MD, Jagger JE et al. Erratum to: 36th International Symposium on Intensive Care and Emergency Medicine: Brussels, Belgium. 15-18 March 2016. Crit Care 2016; 20: 347. doi:10.1186/ s13054-016-1358-6
[41] Ibrahim HM, Mudawi AM, Ghandour IA. Oral health status, knowledge and practice among pregnant women attending Omdurman maternity hospital, Sudan. East Mediterr Health J 2017; 22: 802-809

[42] Adams SH, Gregorich SE, Rising SS et al. Integrating a Nurse-Midwife-Led Oral Health Intervention Into CenteringPregnancy Prenatal Care: Results of a Pilot Study. J Midwifery Womens Health 2017. doi:10.1111/ jmwh.12613

[43] Chawla RM, Shetiya SH, Agarwal DR et al. Knowledge, Attitude, and Practice of Pregnant Women regarding Oral Health Status and Treatment Needs following Oral Health Education in Pune District of Maharashtra: A Longitudinal Hospital-based Study. J Contemp Dent Pract 2017; 18: $371-377$

[44] Lohana MH, Suragimath G, Patange RP et al. A Prospective Cohort Study to Assess and Correlate the Maternal Periodontal Status with Their Pregnancy Outcome. J Obstet Gynaecol India 2017; 67: 27-32. doi:10.1007| s13224-016-0920-0

[45] Lu HX, Xu W, Wong MC et al. Impact of periodontal conditions on the quality of life of pregnant women: a cross-sectional study. Health Qual Life Outcomes 2015; 13: 67. doi:10.1186/s12955-015-0267-8

[46] Machuca G, Khoshfeiz O, Lacalle JR et al. The influence of general health and socio-cultural variables on the periodontal condition of pregnant women. J Periodontol 1999; 70: 779-785. doi:10.1902/jop.1999.70.7. 779

[47] Mishra PS, Marawar PP, Mishra SS. A cross-sectional, clinical study to evaluate mobility of teeth during pregnancy using periotest. Indian J Dent Res 2017; 28: 10-15. doi:10.4103/ijdr.IJDR_8_16

[48] Vergnes JN, Kaminski M, Lelong $N$ et al. Frequency and risk indicators of tooth decay among pregnant women in France: a cross-sectional analysis. PLoS One 2012; 7: e33296. doi:10.1371/journal.pone.0033296

[49] Barbieri W, Peres SV, Pereira CB et al. Sociodemographic factors associated with pregnant women's level of knowledge about oral health. Einstein (Sao Paulo) 2018; 16: eAO4079. doi:10.1590/s1679-45082018ao 4079

[50] Splieth CH, Takriti M, Alani A. Flüchtlinge in Deutschland - Mundgesundheit, Versorgungsbedarfe und deren Kosten. 2017. Online: https://www.dgzmk.de/presse/pressemitteilungen/ansicht/news/ dgzmk-liefert-wissenschaftliche-bestandsaufnahme-zur-oralengesundheit-bei-fluechtlingen.html; last access: 04.10.2018

[51] Schwendicke F, Dorfer CE, Schlattmann P et al. Socioeconomic inequality and caries: a systematic review and meta-analysis. J Dent Res 2015; 94: 10-18. doi:10.1177/0022034514557546

[52] Chaffee BW, Rodrigues PH, Kramer PF et al. Oral health-related qualityof-life scores differ by socioeconomic status and caries experience. Community Dent Oral Epidemiol 2017; 45: 216-224. doi:10.1111/cdoe. 12279

[53] Costa SM, Martins CC, Pinto MQC et al. Socioeconomic Factors and Caries in People between 19 and 60 Years of Age: An Update of a Systematic Review and Meta-Analysis of Observational Studies. Int I Environ Res Public Health 2018; 15: 1775. doi:10.3390/ijerph15081775

[54] Wagle M, D’Antonio F, Reierth E et al. Dental caries and preterm birth: a systematic review and meta-analysis. BMJ Open 2018; 8: e018556. doi:10.1136/bmjopen-2017-018556

[55] Zhong C, Ma KN, Wong YS et al. Oral Health Knowledge of Pregnant Women on Pregnancy Gingivitis and Children's Oral Health. J Clin Pediatr Dent 2015; 39: 105-108

[56] Winn D. Tobacco use and oral disease. J Dent Educ 2001; 65: 306-312

[57] Krüll M, Borstein M. Tabakkonsum: Seine Folgen für die Allgemein- und Mundgesundheit - Teil 2. In: Zahnheilkunde Management Kultur. 2010. Online: https://www.zmk-aktuell.de/fachgebiete/allgemeinezahnheilkunde/story/tabakkonsum-seine-folgen-fuer-die-allgemeinund-mundgesundheit-teil-2_3897.html; last access: 26.11.2019 
[58] Stelmakh V, Slot DE, van der Weijden GA. Self-reported periodontal conditions among Dutch women during pregnancy. Int J Dent Hyg 2016. doi:10.1111/idh. 12210

[59] Günay H, Meyer K, Rahman A. Gesundheitsfrühförderung in der Schwangerschaft-ein Frühpräventionskonzept. Zahnärztl Mitt 2007; 97: 23482358

[60] Statistisches Bundesamt. GENESIS-Online. In: Statistisches Bundesamt; 2019. Online: https://www-genesis.destatis.de/genesis/online/data; sid=0D22F486D62D4F664790ED8FA269B6EB.GO_2_2?operation= begriffsRechercheBlaettern\&levelindex=0\&levelid $=1550916377089$; last access: 23.02.2019

[61] Baumann I. Die korrekte Abrechnung der Leistungen beim Schwangerschaftsvorsorgekonzept. 12.10.2015. Online: https://www.iww.de/pa/ archiv/prophylaxe-die-korrekte-abrechnung-der-leistungen-beimschwangerschaftsvorsorgekonzept-f89163; last access: 23.02.2019

[62] Herrmann P, Meyer K, Sandner M et al. Zahnärztliche Gesundheitsfrühförderung in der Frühen Hilfe - Eine randomisierte Kontrollgruppenstudie. DZZ 2014; 69: 10. doi:10.3238/dzz.2014.0573-0583
[63] Günay H, Dmoch-Bockhorn K, Günay Y et al. Effect on caries experience of a long-term preventive program for mothers and children starting during pregnancy. Clin Oral Investig 1998; 2: 137-142

[64] Meyer K, Khorshidi-Bohm M, Geurtsen W et al. An early oral health care program starting during pregnancy-a long-term study-phase V. Clin Oral Investig 2014; 18: 863-872. doi:10.1007/s00784-013-1059-3

[65] Günay H, Meyer K, Rahman A. Zahnärztliche Gesundheitsfrühförderung in der Schwangerschaft-ein Frühpräventionskonzept. Oralprophylaxe \& Kinderzahnheilkunde 2007; 29: 24-35

[66] Martínez-Beneyto Y, Vera-Delgado MV, Pérez L et al. Self-reported oral health and hygiene habits, dental decay, and periodontal condition among pregnant European women. Int J Gynecol Obstet 2011; 114: 18-22. doi:10.1016/j.ijgo.2011.03.003

[67] Xiong X, Elkind-Hirsch KE, Vastardis S et al. Periodontal disease is associated with gestational diabetes mellitus: a case-control study. J Periodontol 2009; 80: 1742-1749. doi:10.1902/jop.2009.090250 